\title{
Structural Response of Modular Buildings - An Overview
}

\author{
Andrew W Lacey ${ }^{a}$, Wensu Chen ${ }^{a}$, Hong Hao ${ }^{{ }^{*}}$, and Kaiming $\mathrm{Bi}^{\mathrm{a}}$ \\ ${ }^{a}$ Centre for Infrastructure Monitoring and Protection, School of Civil and Mechanical \\ Engineering, Curtin University, Kent Street, Bentley, WA 6102, Australia \\ *hong.hao@curtin.edu.au
}

\begin{abstract}
Prefabrication by off-site manufacturing leads to a reduced overall construction schedule, improved quality, and reduced resource wastage. Modular building is therefore increasingly popular and promoted. With the recent promotion a number of relevant studies have been completed, however, a review of the design, construction, and performance of modular buildings under different loading conditions is lacking. This paper presents a state-of-the-art review of modular building structures. First, structural forms and construction materials are presented as a brief introduction to the modular structures. Modular building is shown to refer not to a single structure type, but a variety of structural systems and materials. These modular structures might perform differently to similar traditional structures and the structural performance is highly dependent on interand intra-module connections. The structural response of modules to different hazards is then considered, followed by the current design practice and methodology. As a currently developing area there is great potential for innovation in modular structures and several key research areas are identified for further work.
\end{abstract}

Keywords: modular building, prefabrication, off-site fabrication, multi-hazard

\section{Introduction}

Modular building is a construction technique whereby building modules are prefabricated offsite. It is a type of off-site fabrication referring specifically to volumetric units which may be a structural element of a building [1-4]. Modular building refers to the application of a variety of structural systems and building materials, rather than a single type of structure. Prefabrication by off-site manufacturing leads to a reduced overall construction schedule, improved quality, and reduced resource wastage [5-7]. The disadvantages include the limitations of existing 
design guidance and module size limits due to transport requirements. The advantages of modular building outweigh the disadvantages particularly for hotel and residential development applications. Modular building is therefore increasingly popular and promoted. With the recent promotion a number of relevant studies have been conducted. This paper presents a state-of-theart review of modular building structures. First, recently developed structural forms and construction materials are presented as a brief introduction to the modular structures. The focus is on steel framed modules with concrete and timber frame modules excluded, not for lack of importance, but for lack of recent research into the structures. Structural connections are the key to overall performance and so a detailed review of connection types is presented. Then, the structural response of modules to different hazards is considered, followed by the potential applications and future research work.

\section{Module classification and developments in structural form}

Modules are classified as steel, precast concrete and timber frame modules according to the primary construction material. Steel modules are further classified as Modular Steel Building (MSB) modules [8], light steel framed modules and container modules. Their applications, advantages and disadvantages are given in Table 1. Load bearing steel modules are also categorised as column supported or continuously supported [9] as shown in Figure 1. Column supported modules have edge beams which span between corner or intermediate columns. Continuously supported modules have load bearing walls which provide continuous support [9, 10]. Three examples of steel modules are shown in Figure 2. The examples of precast concrete and timber framed modules are also shown in Figure 3.

Recent study of modular building was focussed on light steel framing applied to modular buildings [9-13], followed by consideration of overall building design using modules [14], and then high-rise building applications [5, 15]. A broad overview of modular construction using light steel framing was given with the application of relevant British and European standards. Several types of modular construction have been presented. Many modular buildings are not exclusively modular but are hybrid structures. Modular construction is combined with a primary steel or concrete structure, for example, using a podium or skeletal structure, or a concrete core around which modules are arranged $[5,12,15]$. Column supported MSBs are well suited to medium and high-rise building applications and popularly used in current practice. They have been developed through the research of Annan [8], Fathieh [16] and Gunawardena [17]. Annan [8] presented a summary of traditional steel building systems and appropriate analysis procedures, documented detailing requirements, reviewed floor connections and explored seismic behaviour [18-21]. Fathieh [16] contributed to the review of MSBs subject to earthquake loading [22]. Gunawardena et al. [23] subsequently extended the application of 
MSBs. Noting that many modular buildings are not exclusively modular, a new system was presented with strategically placed stiff modules replacing the conventional core structure [23]. Gunawardena et al. [24] refined the module design and demonstrated that modular buildings can be self-stable for a ten-storey building subject to earthquake ground motion. The dynamic behaviour of high-rise MSBs remains to be investigated [22].

Table 1. Module classification

\begin{tabular}{lllll}
\hline Category & Applications & Advantages & Disadvantages & Ref. \\
\hline $\begin{array}{l}\text { Steel }- \\
\text { MSB } \\
\text { module }\end{array}$ & $\begin{array}{l}\text { Hotel, residential } \\
\text { apartments }\end{array}$ & $\begin{array}{l}\text { Suited to high rise } \\
\text { buildings, high strength }\end{array}$ & $\begin{array}{l}\text { Corrosion, lack of design } \\
\text { guidance }\end{array}$ & $\begin{array}{l}{[18-} \\
24]\end{array}$ \\
\hline $\begin{array}{l}\text { Steel }- \\
\text { Light steel } \\
\text { framed } \\
\text { module }\end{array}$ & $\begin{array}{l}\text { Max. 10-storey, 25- } \\
\text { storey with additional } \\
\text { core }\end{array}$ & Lightweight & $\begin{array}{l}\text { Suited to low rise } \\
\text { buildings }\end{array}$ & {$\left[\begin{array}{l}{[4,5,} \\
9-15,\end{array}\right.$} \\
\hline $\begin{array}{l}\text { Steel }- \\
\text { Container } \\
\text { module }\end{array}$ & $\begin{array}{l}\text { Post-disaster housing, } \\
\text { military operations, and } \\
\text { residential } \\
\text { developments }\end{array}$ & $\begin{array}{l}\text { Recycle shipping } \\
\text { containers, easy transport }\end{array}$ & $\begin{array}{l}\text { Additional reinforcing } \\
\text { required to strengthen } \\
\text { container when openings } \\
\text { are cut in wall }\end{array}$ & {$[26-$} \\
\hline $\begin{array}{l}\text { Precast } \\
\text { concrete } \\
\text { module }\end{array}$ & $\begin{array}{l}\text { Hotel, prison, secure } \\
\text { accommodation }\end{array}$ & $\begin{array}{l}\text { Fire resistance, acoustic } \\
\text { insulation, thermal } \\
\text { performance, high mass }\end{array}$ & $\begin{array}{l}\text { Heavy, potential cracking } \\
\text { at corners }\end{array}$ & {$[4]$} \\
& & $\begin{array}{l}\text { helps meet vibration } \\
\text { criteria, high capacity }\end{array}$ & & \\
\hline $\begin{array}{l}\text { Timber } \\
\text { frame } \\
\text { module }\end{array}$ & $\begin{array}{l}\text { 1- to 2-storey, } \\
\text { education buildings, } \\
\text { housing }\end{array}$ & $\begin{array}{l}\text { Sustainable material, easy } \\
\text { to fabricate }\end{array}$ & $\begin{array}{l}\text { Poor fire resistance, } \\
\text { durability }\end{array}$ & {$[4$,} \\
\hline
\end{tabular}

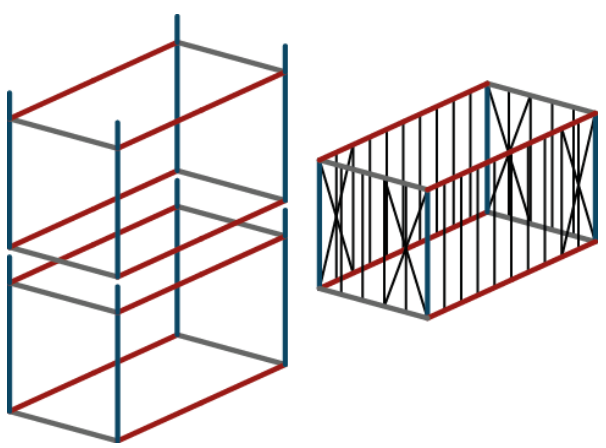

Figure 1: (L) Column supported modules and (R) Continuously supported modules (after Gorgolewski et al. [9])

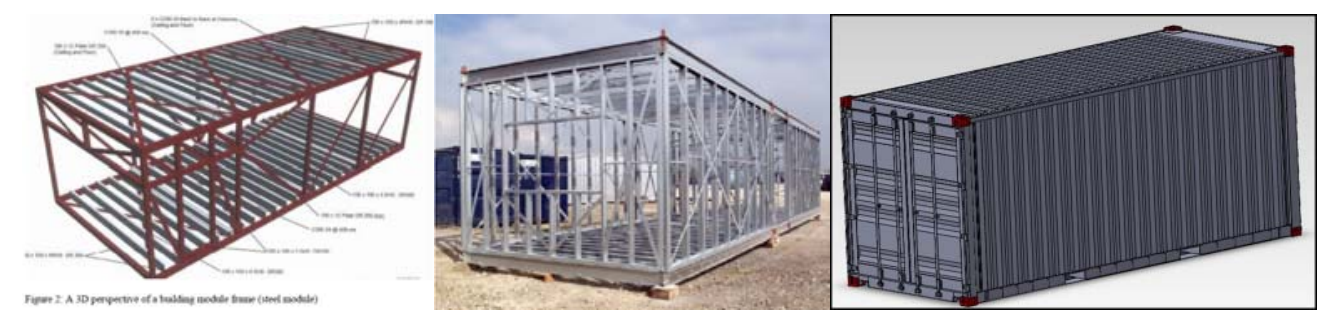

Figure 2: (L) Modular steel building [31], (M) Light steel framed module [12], (R) Shipping container [26] 


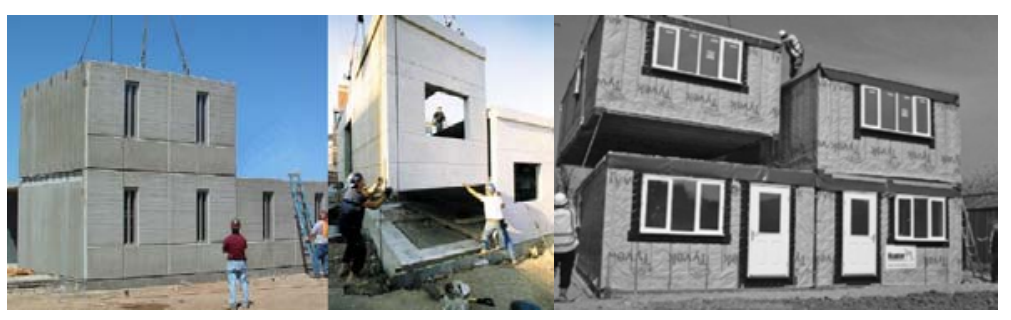

Figure 3: (L) Precast concrete modules [17]; (R) Timber frame modules [4]

\section{Component materials}

Prefabricated components should be as light as possible as they are transported sometimes long distances. Traditional materials of steel, concrete and timber are commonly used. The potential applications of composite sandwich structures have not been well explored [32]. Manalo et al. [33] gives an overview of fibre reinforced polymer (FRP) sandwich systems in the context of lightweight civil infrastructure. Many of the developing materials presented by Manalo et al. [33] may find application in modular buildings. To date such composite systems have been developed for application as roof, wall or floor components. Some examples of composite materials are given in Table 2. Use of FRP composite materials for complete modular building façades is appealing although their performance, especially with respect to wind-borne debris impact and fire, is a developing area. In addition, the design and manufacture of reliable jointing systems is noted as a challenge which has received growing research attention [33].

Table 2. Composite materials with application in modular buildings

\begin{tabular}{|c|c|c|c|}
\hline Use & Composite material & Advantages & Ref. \\
\hline Wall & $\begin{array}{l}\text { Rigid polyurethane foam stud } \\
\text { frame with magnesium oxide } \\
\text { cladding }\end{array}$ & Environment, lightweight, low cost & {$[32]$} \\
\hline Floor & $\begin{array}{l}\text { Glass FRP web-flange sandwich, } \\
\text { adhesively bonded }\end{array}$ & $\begin{array}{l}\text { Lightweight, strength, high serviceability } \\
\text { stiffness, corrosion resistance, low thermal } \\
\text { conductivity }\end{array}$ & $\begin{array}{l}{[34,} \\
35]\end{array}$ \\
\hline Floor & FRP-steel composite beam system & $\begin{array}{l}\text { Lightweight, high strength, corrosion resistance, } \\
\text { low thermal conductivity }\end{array}$ & $\begin{array}{l}{[36,} \\
37]\end{array}$ \\
\hline Floor & $\begin{array}{l}\text { Glass fibre reinforced cement, } \\
\text { polyurethane, steel laminate }\end{array}$ & Lightweight, acceptable strength, $5 \%$ damping & $\begin{array}{l}{[38,} \\
39]\end{array}$ \\
\hline Floor & Steel-timber composite & Lightweight, sustainable & $\begin{array}{l}{[40-} \\
42]\end{array}$ \\
\hline $\begin{array}{l}\text { Floor } \\
\text { Roof }\end{array}$ & $\begin{array}{l}\text { Cold-formed steel - timber sheet } \\
\text { composite beam, or truss }\end{array}$ & $\begin{array}{l}\text { Lightweight, efficient material use, simple } \\
\text { fabrication, low cost, renewable and reusable } \\
\text { materials }\end{array}$ & $\begin{array}{l}{[43,} \\
44]\end{array}$ \\
\hline
\end{tabular}

\section{Connection systems}

Interconnection of frame members and modules is critical to the capability of modular buildings to withstand applied loads [45]. Despite the need for a thorough understanding, studies on the connections are limited [45]. Connections are grouped into three types: inter-module, intra- 
module, and module to foundation as shown in Figure 4. Table 3 provides a summary of connections for steel modules with further details given in the following sections.

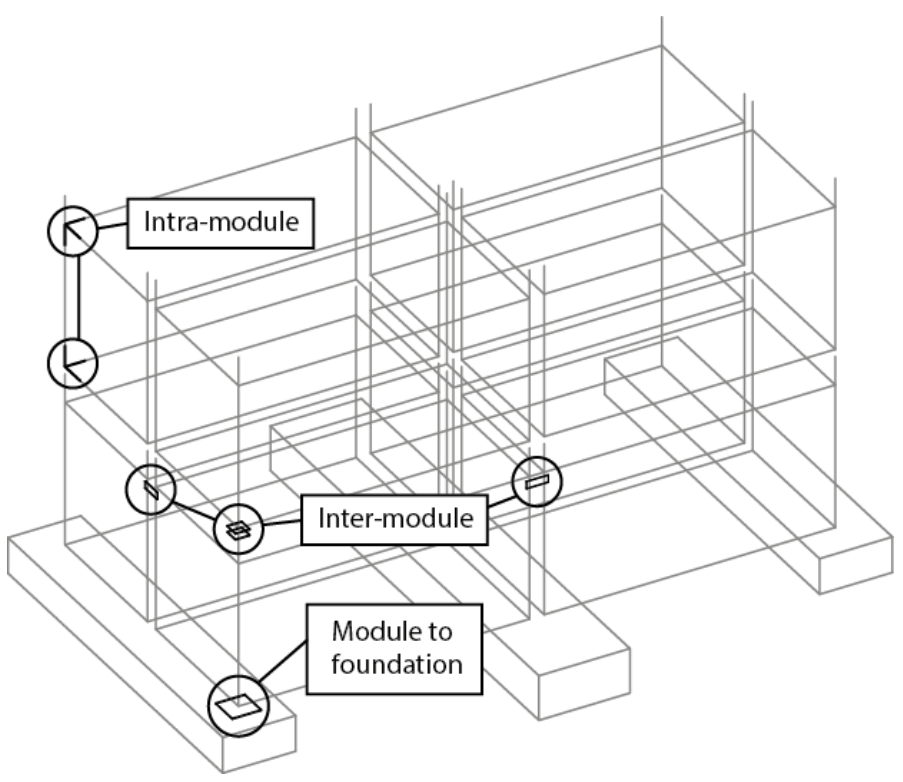

Figure 4. Illustration of connection types

Table 3. Summary of connection types

\begin{tabular}{|c|c|c|c|}
\hline Type & Sub-Type & Advantage & Disadvantage \\
\hline \multirow[t]{3}{*}{ Inter-module } & Bolted & $\begin{array}{l}\text { Reduced site work; } \\
\text { demountable }\end{array}$ & $\begin{array}{l}\text { Access, slotted holes, slip, bolt } \\
\text { tensioning }\end{array}$ \\
\hline & $\overline{\text { Welded }}$ & $\begin{array}{l}\text { No slip, compact, } \\
\text { accommodate misalignment }\end{array}$ & $\begin{array}{l}\text { Site work, corrosion, not } \\
\text { demountable }\end{array}$ \\
\hline & $\begin{array}{l}\text { Composite (concrete- } \\
\text { steel) }\end{array}$ & Strength, no slip, compact & Site work, not demountable \\
\hline \multirow[t]{2}{*}{ Intra-module } & Bolted & $\begin{array}{l}\text { Tolerance for shop } \\
\text { assembly, deconstructable }\end{array}$ & $\begin{array}{l}\text { Relatively low moment capacity, } \\
\text { ductility and rotation capacity }\end{array}$ \\
\hline & $\overline{\text { Welded }}$ & $\begin{array}{l}\text { Suited to factory based } \\
\text { construction using jig to } \\
\text { ensure module uniformity }\end{array}$ & $\begin{array}{l}\text { Does not permit rotation, steel } \\
\text { members should be designed for } \\
\text { hogging moments and axial } \\
\text { forces }\end{array}$ \\
\hline \multirow[t]{4}{*}{$\begin{array}{l}\text { Module to } \\
\text { foundation }\end{array}$} & $\begin{array}{l}\text { Chain/cable/keeper } \\
\text { plate }\end{array}$ & Low cost & $\begin{array}{l}\text { Limited to low rise construction; } \\
\text { tensioning requirements }\end{array}$ \\
\hline & $\begin{array}{l}\text { Site weld to base } \\
\text { plate }\end{array}$ & Rigid connection & $\begin{array}{l}\text { Additional trade on site, hot } \\
\text { work, damage to steel corrosion } \\
\text { protection system }\end{array}$ \\
\hline & $\begin{array}{l}\text { Base plate - cast in } \\
\text { anchor bolts }\end{array}$ & Ductility & $\begin{array}{l}\text { Positioning of cast in anchor } \\
\text { bolts, tolerance in steel base } \\
\text { plate, corrosion }\end{array}$ \\
\hline & $\begin{array}{l}\text { Base plate embedded } \\
\text { in concrete }\end{array}$ & $\begin{array}{l}\text { Full column strength and } \\
\text { good ductility }\end{array}$ & $\begin{array}{l}\text { Positioning of column during } \\
\text { concrete curing, site welding }\end{array}$ \\
\hline
\end{tabular}

\subsection{Inter-module connection}

Inter-module connection includes horizontal connections (HC) between adjacent modules in two plan directions, and vertical connection (VC) between stacked modules. It is reported that 
bolted connection is preferred over site welding. A gap is usually provided between the floor and ceiling beams, as shown in Figure 1(L), allowing for external access to inter-module connections and for services to pass between the beams. This suits connection between the columns, rather than between the beams. Bolted connections can be complex to accommodate connection of modules stacked in three directions while ensuring access to fasteners is provided during the install sequence. Use of long slotted holes may introduce the potential for tolerance accumulation over multiple levels, and vulnerability to slip failure in the event of large horizontal force [17]. The potential for connection slip may be controlled with the use of friction-grip or pre-tensioned bolts. VCs may incorporate a shear key or spigot [46], which assists in positioning modules and may provide structural connection where physical access is not possible or practical. In some cases, concrete or grout is used to lock the joint in place, creating a composite concrete-steel connection. Table 4 presents a summary of inter-module connections for steel modules from the literature, and identifies the numerical and experimental investigation completed. In the latest studies, force-displacement (F-d) and moment-rotation (M$\theta$ ) behaviours of the connection are established by detailed numerical analysis of the connection (see also Section 7).

Table 4. Inter-module connection types

\begin{tabular}{|c|c|c|c|c|}
\hline Type & Illustration & Ref. & Description & $\begin{array}{l}\text { Numerical / Experimental } \\
\text { Study }\end{array}$ \\
\hline $\mathrm{HC}$ & & $\begin{array}{l}9 \\
22]\end{array}$ & $\begin{array}{l}\text { Tie plate, connecting } \\
\text { hollow or open steel } \\
\text { section columns }\end{array}$ & - \\
\hline $\mathrm{HC}$ & 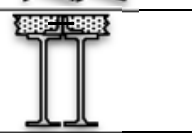 & $\begin{array}{l}{[18-} \\
21]\end{array}$ & $\begin{array}{l}\text { In-situ concrete encased } \\
\text { bolted cleat, connecting } \\
\text { open steel section beams }\end{array}$ & - \\
\hline $\mathrm{HC}$ & & {$[47]$} & $\begin{array}{l}\text { Bolted side plate, } \\
\text { connecting hollow steel } \\
\text { sections (HSS) }\end{array}$ & $\begin{array}{l}\text { Numerical - Load- } \\
\text { displacement (F-d) and } \\
\text { moment-rotation (M- } \theta \text { ) }\end{array}$ \\
\hline $\mathrm{VC}$ & & $\begin{array}{l}{[18-} \\
21]\end{array}$ & $\begin{array}{l}\text { Site weld end plate (one } \\
\text { side), connecting HSS }\end{array}$ & - \\
\hline $\mathrm{VC}$ & & [4] & $\begin{array}{l}\text { Bolted end plate, } \\
\text { connecting HSS with } \\
\text { access hole, or open angle } \\
\text { section columns }\end{array}$ & - \\
\hline $\mathrm{VC}$ & & {$[46]$} & $\begin{array}{l}\text { Lifting plate shear key, } \\
\text { connecting HSS }\end{array}$ & - \\
\hline $\mathrm{VC}$ & & {$[48]$} & $\begin{array}{l}\text { Bolted connection, } \\
\text { connecting open steel } \\
\text { section beams }\end{array}$ & $\begin{array}{l}\text { Numerical - F-d in 1-direction } \\
\text { (compression) and M- } \theta \text { in 2- } \\
\text { directions }\end{array}$ \\
\hline $\mathrm{VC}$ & & {$[47]$} & $\begin{array}{l}\text { Bolted end plate (bolts on } \\
\text { two sides), connecting } \\
\text { HSS }\end{array}$ & Numerical - F-d and M- $\theta$ \\
\hline $\mathrm{VC} / \mathrm{HC}$ & & {$[17]$} & $\begin{array}{l}\text { Complex bolted end plate, } \\
\text { connecting HSS }\end{array}$ & $\begin{array}{l}\text { Numerical and experimental - } \\
\text { F-d in 1-direction (shear) }\end{array}$ \\
\hline
\end{tabular}




\begin{tabular}{|l|l|l|l|}
\hline $\mathrm{VC} / \mathrm{HC}$ & $\begin{array}{l}{[49,} \\
50]\end{array}$ & $\begin{array}{l}\text { Bolted connection plate, } \\
\text { connecting HSS }\end{array}$ & $\begin{array}{l}\text { Numerical - M- } \theta \text { in 1- } \\
\text { direction, cyclic loading }\end{array}$ \\
\hline $\mathrm{VC} / \mathrm{HC}$ & {$[51]$} & $\begin{array}{l}\text { Steel bracket welded to } \\
\text { corner columns }\end{array}$ & $\begin{array}{l}\text { Numerical and experimental - } \\
\text { Shear and simply supported }\end{array}$ \\
\hline $\mathrm{VC} / \mathrm{HC}$ & $\begin{array}{l}\text { Steel bracket, bolted or } \\
\text { welded to floor and } \\
\text { ceiling beams }\end{array}$ & $\begin{array}{l}\text { Numerical and experimental - } \\
\text { M- } \theta \text { in 1-direction, cyclic } \\
\text { loading }\end{array}$ \\
\hline $\mathrm{VC} / \mathrm{HC}$ & {$[53]$} & $\begin{array}{l}\text { Pre-tensioned connection } \\
\text { of columns } \\
\text { (Composite steel- } \\
\text { concrete) }\end{array}$ & $\begin{array}{l}\text { Numerical and experimental - } \\
\text { Simply supported, static and } \\
\text { cyclic loading }\end{array}$ \\
\hline $\mathrm{VC} / \mathrm{HC}$ & {$\left[\begin{array}{l}\text { Bolted interior steel } \\
\text { connection }\end{array}\right.$} & $\begin{array}{l}\text { Numerical and experimental - } \\
\text { Lateral loading of beam- } \\
\text { column assembly, static and } \\
\text { cyclic loading }\end{array}$ \\
\hline
\end{tabular}

\subsection{Intra-module connection}

Intra-module connections, i.e. connections within a module, are generally representative of traditional connection details. For MSBs both welded and bolted connections are used.

Considering column to beam connections, the bolted connection types include single web (or fin) plates $[4,55,56]$, double angle cleats [47], and bolted end plates [56]. It is suggested that a moment resisting connection consisting of an end plate or a deep fin plate may provide lateral stiffness for low rise buildings [4]. This is unusual in that fin plate connections are often classified as simple shear connections. Fin plate connections have relatively low moment capacity, ductility and rotation capacity [57], hence their use is suggested only for low rise (3storey or less) buildings [4]. However, the use of such connections may make open modules susceptible to progressive collapse [57]. In this case the fin plate connection may have inadequate moment capacity, and so require strengthening. In contrast, Annan et al. [19] investigated steel floor framing with secondary beams welded directly to the main beams. This is compared with conventional steel construction which may use clip angles permitting greater rotation. The welded connections do not necessarily permit rotation such that steel members should be designed for hogging moments and axial forces which may be developed as a result [19]. Linear elastic analysis is demonstrated to be adequate for this issue and Annan et al. [19] 
present a process which may be adopted in design.

\subsection{Module to foundation connection}

Foundations may consist of in situ or precast concrete footings, bored concrete piles, augered steel piles, or some combinations. Low rise modular buildings located in areas with high lateral loading may be vulnerable to overturning and sliding failures if not adequately restrained by connection to an appropriate foundation. Building modules are commonly connected by chains, cables, keeper plates or welding to concrete or steel piles, or large mass concrete footings. Each connection type has associated disadvantages including tensioning requirements for chain and cable. In medium and high-rise construction foundations are more substantial. Base plates may be incorporated in modules and fixed to cast-in anchors, or welded on site to accessible cast-in plates. Park et al. [45] developed an embedded column connection (Figure 5), as an alternative to the traditional cast-in or post-fixed steel bearing plate. This connection was developed to ensure best use of the full column strength and provide good ductility. The disadvantages include the requirement for site welding between MSB columns and the end plate.

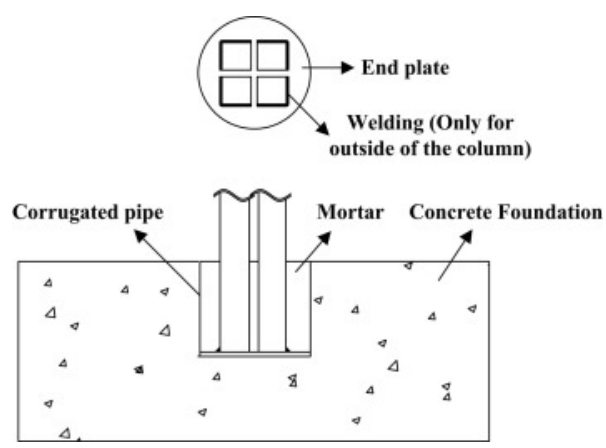

Figure 5. Embedded column connection [45]

\section{Case study}

To define the range of existing modular buildings, a list of multi-storey modular building projects has been compiled based on a review of the literature. Table 5 shows a selected sample. The tallest identified prefabricated building is J57 Mini Sky City located in Changsha, China, being 57 storeys or $207.8 \mathrm{~m}$ tall [30]. In Australia, the tallest prefabricated building identified is La Trobe Tower, Melbourne, being 44 storeys or $133 \mathrm{~m}$ tall. It is in an area with relatively low wind and earthquake loading. In areas with higher lateral load requirements the maximum building height is less. For example, the tallest building within Australia's severe cyclone region is Concorde South, being 6 storeys.

Table 5. Selected modular building projects

\begin{tabular}{lllll}
\hline Project & Location & Storeys & Use & Completed \\
\hline
\end{tabular}




\begin{tabular}{lllll}
\hline $\begin{array}{l}\text { Agricola College Student } \\
\text { Accommodation }\end{array}$ & Kalgoorlie, Australia & 4 & $\begin{array}{l}\text { Student } \\
\text { Accommodation }\end{array}$ & 2017 \\
\hline La Trobe Tower & Melbourne, Australia & 44 & Residential & 2016 \\
\hline 461 Dean Street & New York City, United States & 32 & Residential & 2016 \\
\hline Coast Apartments & Rockingham, Australia & 4 & Residential & 2016 \\
\hline J57 Mini Sky City & Changsha, China & 57 & $\begin{array}{l}\text { Residential / } \\
\text { office }\end{array}$ & 2015 \\
\hline Concorde South & South Hedland, Australia & 6 & Residential & 2014 \\
\hline SOHO Apartment & Darwin, Australia & 29 & $\begin{array}{l}\text { Residential / } \\
\text { Hotel }\end{array}$ & 2014 \\
\hline $\begin{array}{l}\text { Unite Student Apartment / } \\
\text { Hostel }\end{array}$ & Wembley, England & 19 & $\begin{array}{l}\text { Student } \\
\text { Accomm. }\end{array}$ & 2014 \\
\hline Port View Apartments & Port Hedland, Australia & 4 & Residential & 2013 \\
\hline Little Hero Building & Melbourne, Australia & 8 & Residential & 2010 \\
\hline Victoria Hall & Wolverhampton, England & 25 & Student Accom. & 2009 \\
\hline Paragon Student Housing & West London, England & 17 & Student Accom. & 2006 \\
\hline $\begin{array}{l}\text { Royal Northern College of } \\
\text { Music }\end{array}$ & Manchester, England & 9 & Student Accom. & 2001 \\
\hline
\end{tabular}

\section{Hazards and structural responses}

The hazards for modular buildings include transport activity, cyclone (hurricane, tornado), earthquake, explosion, progressive collapse, and fire. Hazards can be classified as natural, anthropogenic, or technological $[58,59]$ and the interaction can be concurrent, cascading or independent [60]. Each hazard has associated actions, or loads, for which the building structure must be designed. Different loads have different characteristics, design criteria and mitigation strategies (Table 6). No studies have been identified to address the method for selection of an optimal design to suit the competing requirements of different loads for modular building.

Table 6. Summary of load characteristics and design criteria

\begin{tabular}{|c|c|c|}
\hline Load & Characteristics & Design Criteria \\
\hline $\begin{array}{l}\text { Transport \& } \\
\text { Handling }\end{array}$ & $\begin{array}{l}\text { Lifting: dynamic amplification } \\
\text { depending on module and lift } \\
\text { arrangement; } \\
\text { Transport: acceleration coefficients in } \\
\text { three orthogonal directions }\end{array}$ & $\begin{array}{l}\text { Stability, strength and serviceability; } \\
\text { Deflection criteria to protect components, e.g. } \\
\text { h/500, L/500 }\end{array}$ \\
\hline Wind Load & $\begin{array}{l}\text { Low frequencies, } \sim 0.01 \text { to } 2.5 \mathrm{~Hz} \\
\text { Mean component and fluctuating } \\
\text { component (gust-factor approach) }\end{array}$ & $\begin{array}{l}\text { Stability, strength, serviceability (inter-storey \& } \\
\text { overall deflection, and vibration); } \\
\text { Deflection limits for serviceability limit state, } \\
\text { e.g. H/600 for total drift and h/500 for inter- } \\
\text { storey drift [61] }\end{array}$ \\
\hline $\begin{array}{l}\text { Debris } \\
\text { Impact }\end{array}$ & Local impact & $\begin{array}{l}\text { Local penetration, opening area for internal } \\
\text { pressure calculation }[62,63]\end{array}$ \\
\hline Earthquake & $\begin{array}{l}\text { Ground motion with frequency } \\
\text { contents in the range of } 0.5 \text { to } 25 \mathrm{~Hz} \text {; } \\
\text { Excites fundamental, low vibration } \\
\text { modes resulting in a global structural } \\
\text { response }\end{array}$ & $\begin{array}{l}\text { Damage criteria - displacement based i.e. } \\
\text { ductility ratio \& inter-storey drift e.g. } 1.5 \% \text { inter- } \\
\text { storey drift [64] } \\
\text { Design criteria - life safety, collapse prevention }\end{array}$ \\
\hline Blast & $\begin{array}{l}\text { Short duration; local response for } \\
\text { close-in blast, might lead to } \\
\text { progressive collapse; }\end{array}$ & $\begin{array}{l}\text { Descriptive building damage level and } \\
\text { component response }\end{array}$ \\
\hline
\end{tabular}




\begin{tabular}{lll}
\hline & $\begin{array}{l}\text { For far field blast, uniformly } \\
\text { distributed loading }\end{array}$ & \\
\hline Fire & High temperature & Fire resistance level (time) \\
\hline
\end{tabular}

\subsection{Transport and handling}

Modules are designed to be lifted, with designated lift points provided on the module. They are usually lifted by a crane, although forklifts may be used in the manufacturer's yard. The number and positioning of lift points is often determined by deflection criteria chosen to protect fragile components. Lift points are typically positioned in from each end, reducing member design actions and deformation of the chassis. General guidance on the design of lifters is available in existing documents, for example, American Standard [65-67] and DNV Offshore Standard [68]. The stiffness of a whole module is likely to be influenced by internal and external linings and manufacturers may test complete modules to establish composite stiffness. For transportation, including road, rail and sea, the loading is defined by acceleration coefficients, for example $0.8 \mathrm{~g}$ forward, $0.5 \mathrm{~g}$ rearward, and $0.5 \mathrm{~g}$ transverse during road transportation. General guidance is available in the existing documents, for example, the CTU Code [69] for cargo transport units (CTU). Transit bracing is often provided, particularly in open modules, to strengthen the structural frame and increase stiffness to help control damage to fragile components.

Few studies on the response of modular buildings to transport and handling have been reported. Smith et al. [70] investigated transport and handling for single storey timber framed modules. Field testing and numerical modelling using SAP2000 were conducted and the relevant data is provided in the referenced report. It was reported that the main form of damage was cracking of internal plasterboard linings. This was caused by the lifting practices with road transport propagating cracks. It was recommended that areas for further work included the development of laboratory techniques to simulate transport under controlled conditions and the development of dampers to reduce dynamic forces.

\subsection{Wind}

Natural hazards such as cyclones and tornadoes encompass multiple actions including both primary wind loading, and secondary debris impact and water ingress. Wind loads are characterised by low frequencies, approximately 0.01 to $2.5 \mathrm{~Hz}$, and mean and fluctuating components [71-73]. Design criteria are typically based on stability, strength and serviceability by considering inter-storey deflection, overall deflection, and vibration [74]. For example, the limits of $\mathrm{H} / 600$ for total building drift and $\mathrm{h} / 500$ for inter-storey drift [61] are specified, where $\mathrm{H}$ is the total building height and $\mathrm{h}$ is the storey height. Generally, structures are regarded as wind sensitive if the fundamental frequency is less than $1 \mathrm{~Hz}$, and slenderness ratio is greater than five $[62,74,75]$. Static analysis is therefore appropriate for buildings with height less than 
$50 \mathrm{~m}$ [74], based on an empirical formula for the fundamental frequency [76, 77]. However, results presented in the literature for modular buildings suggest a value of $30 \mathrm{~m}$ could be more appropriate, with a frequency of approximately $1 \mathrm{~Hz}$ obtained numerically for a 10 -storey modular building [17] (refer Section 6.3.3). Therefore, dynamic analysis is required for modular buildings over $30 \mathrm{~m}$ high. No studies are identified to address cyclonic wind loads for modular buildings.

Few studies on the response of modular structures to wind loading have been conducted. Gunawardena et al. [78] presented base shear and storey drift results for static analysis of a 10-storey modular building with wind loading applied following AS 1170.2:2011 [62] for Region A, Terrain Category 4. Three different cases of inter-connection were considered for this building - rigid connection by a rigid floor diaphragm, flexible connection by a semi-rigid diaphragm, and no connection. The results indicated the actual structural behaviour fell between that for the semi-rigid diaphragm and no diaphragm. Styles et al. [47] investigated the effect of joint rotational stiffness on the response to wind loading for an 11storey modular building. It was reported that increasing horizontal inter-module and intramodule connection stiffness effectively reduced inter-storey drift due to wind load. Intramodule connection stiffness was shown to have a greater effect than horizontal inter-module connection stiffness. It is indicated that further studies are needed to address the factors including vertical inter-module connection stiffness and building height.

\subsubsection{Wind-borne debris}

Wind-borne debris impact has been observed in many strong wind events and is well documented in the existing literature [79-81]. Debris impact causes localised damage and if the envelope is penetrated may cause additional damage due to water ingress and internal pressurisation. Debris impact loading is typically specified for standard debris items, with velocity related to regional wind speed $\left(\mathrm{V}_{\mathrm{R}}\right)$. For example, AS/NZS 1170.2 [62] specifies a $4 \mathrm{~kg}$ timber with $100 \times 50 \mathrm{~mm}$ cross-section impacting at $0.4 \mathrm{~V}_{\mathrm{R}}$ and $0.1 \mathrm{~V}_{\mathrm{R}}$, and an $8 \mathrm{~mm}(2 \mathrm{~g})$ steel ball impacting at $0.4 \mathrm{~V}_{\mathrm{R}}$ and $0.3 \mathrm{~V}_{\mathrm{R}}$ for the vertical and horizontal trajectory component respectively [62]. Modular buildings are generally lightweight to facilitate transport and so may incorporate lightweight cladding materials which are vulnerable to debris impact. Recently, a systematic study of the performances of structural panels against wind-borne debris impact has been conducted experimentally by using a pneumatic cannon and numerically by using LS-DYNA [82-86] and some cost-effective engineering adaptation methods have been developed. The development of lightweight and resilient structural panel as building envelope can be incorporated into the design of modular buildings. 


\subsection{Earthquake}

Earthquakes are characterised by ground motions with predominant frequencies in the range of 0.5 to $25 \mathrm{~Hz}$, which normally excite the fundamental and low vibration modes of engineering structures and result in global structural responses [71, 72]. Extensive research works have been carried out to investigate the seismic behaviours of traditional building structures, and displacement-based damage criteria such as the ductility ratio and inter-storey drift ratio are widely used by the design guides to measure their seismic performances [72]. For example, Australian Seismic Design Code AS 1170.4 [64] specifies an inter-storey drift limit of $1.5 \%$ for the ultimate limit state. Modular buildings, due to their obvious advantages, are increasingly used in areas with high seismic hazard. Their seismic performances are, however, not adequately understood because they are a relatively new structural form. The rocking and sliding response of modules after connection damage could be the governing response modes. In such cases the conventional displacement-based criteria such as drift ratio may no longer be applicable to quantify modular building damage. Therefore, it is essential to investigate the performance of modular buildings under earthquake loadings and further propose the corresponding criteria to evaluate their seismic performances.

\subsubsection{Seismic responses}

Very limited studies on the seismic responses of modular structures have been conducted and these studies mainly focused on the MSB-braced frames. Annan et al. [20] conducted experimental studies on the hysteretic behaviours of an MSB-braced frame and a regular concentrically-braced frame with similar physical characteristics. It is reported that both specimens showed stable and ductile behaviour up to very high drift ratio (3.5\%). The MSB frame was more vulnerable to column bending deformation, whereas the traditional frame was vulnerable to the out of plane buckling of bracing. Annan et al. [21] further conducted incremental dynamic analysis (IDA) for 2-, 4- and 6-storey two-dimensional (2D) MSB-braced frames. It is reported that the selected MSB-braced frames exhibit a predominantly first-mode response (e.g. the mass participation factors for the 2 -storey frame are $94 \%$ for the $1^{\text {st }}$ mode and $5 \%$ for $2^{\text {nd }}$ mode, similarly, for the 4 -storey frame, the percentages are $81 \%$ and $15 \%$ respectively, and for the 6-storey frame, the values are $77 \%$ and $17 \%$ ) and limited redistribution of internal forces can result in concentration of inelasticity at the first level. Fathieh and Mercan [22] conducted non-linear static pushover and IDA analyses for 2D and 3D MSB-braced 4storey frames. It verified the concentration of inelasticity at the first level due to limited internal force redistribution and brace inelasticity, and found the 2D model overestimated the structural capacity against incipient collapse because torsional response was not accounted for in the 2D model. Gunawardena et al. [24] conducted non-linear time history analysis for a freestanding 
10-storey modular building subject to six selected ground motions. Column hinge formation was found unavoidable in severe ground motions and column ductility was important to redistribute post yield loads. It was indicated that further studies are needed to investigate dynamic behaviours for mid- to high-rise modular buildings.

\subsubsection{Over-strength and ductility}

In the seismic analyses of traditional engineering structures, forces derived from an elastic response spectrum analysis are adjusted to allow for the ductility and other reserved strength. AS 1170.4 adopts a structural ductility factor $(\mu)$ and structural performance factor $\left(S_{p}\right)$ as a measure of the ability to withstand inelastic displacement and other reserved strength respectively. For the modular structures, Annan et al. [18] investigated the inelasticity of modular buildings by conducting non-linear static pushover analyses for 2-, 4- and 6-storey 2D MSB-braced frames. The over-strength factor $\left(\mathrm{R}_{0}=1 / \mathrm{S}_{\mathrm{p}}\right)$ and structural ductility $(\mu)$ are reported as per the National Building Code of Canada (NBCC) [87, 88]. Two methods were used to calculate the column actions due to bracing - the SRSS (Square Root of the Sum of the Squares) method $[89,90]$, and the DS (Direct Summation) method. The SRSS method was found to be unconservative and so the DS approach was recommended. The ductility, which is calculated as the ratio of the ultimate drift $\left(\Delta_{\mathrm{u}}\right)$ to the yield displacement $\left(\Delta_{\mathrm{y}}\right)$ i.e. $\Delta_{\mathrm{u}} / \Delta_{\mathrm{y}}$, is shown to reduce with increasing MSB frame height. The values range from 4.6 to 1.8 for 2- to 6-storey MSBbraced frames. The variation with height is reported to occur for two reasons. First, the yield displacement of braces increases with increasing frame height due to a decrease in brace slenderness (i.e. the brace section size is not constant) [18]. Second, the ultimate drift is determined by the redistribution of load after the compression brace yields [18]. The vertical inter-module connections affect this ability to redistribute load, and the affect increases with increasing frame height [18]. Similarly, the over-strength factor, which is calculated as the ratio of the ultimate load to the design load, is shown to reduce with increasing height [18]. The values range from 2.5 to 1.9 for 2- to 6-storey MSB-braced frames. The variation with height is again related to the ability to redistribute internal force [18]. Similar results are reported for steel moment resisting frame (SMRF) modules. Choi et al. [49] conducted non-linear static pushover analyses for 3- and 5-storey SMRF modules with varying inter-module connection type and stiffness, and reported over-strength factors between 2.15 and 3.76 for the 3-storey frames, and between 1.19 and 1.94 for the 5-storey frames. For each frame height, the SMRF frames with greater inter-connection stiffness had greater over-strength factor.

\subsubsection{Fundamental period of modular building}

The fundamental period of a modular building is an important parameter for the prediction of its 
seismic behaviour [91]. Many standards provide empirical formula for the fundamental period ( $\mathrm{T}_{1}[\mathrm{~s}]$ ) of traditional building structures. For example, AS 1170.4 [64] gives $T_{1}=1.25 k_{t} h_{n}^{0.75}$, where $h_{n}$ is the height from the base to the uppermost seismic mass in metres, and $k_{t}$ is a constant depending on the structure type with a value ranging between 0.05 (for all other structures) and 0.11 (for moment-resisting steel frames). Recently, some studies have been carried out on modular buildings. Figure 6 shows the fundamental periods for rectangular modular buildings together with the upper and lower bounds defined in AS 1170.4. These fundamental periods are the result of numerical analysis of 2D MSB-braced frames [21], 3D MSB-braced frames [17, 22] and steel moment resisting frame (SMRF) modules [49, 92], and experimental analysis of stacked timber frame modules [93]. It can be seen that the period values follow the trend of increasing with building height. From the limited data presented, $\mathrm{k}_{\mathrm{t}}=0.05$ gives a reasonable estimate for both the 2D MSB-braced frames and the timber frame modules. $\mathrm{k}_{\mathrm{t}}=0.075$ appears more appropriate for the 3D MSB-braced frames. For the SMRF modules greater variation in the fundamental period is shown. This is the result of varying intermodule connection type and stiffness [49], and varying imposed gravity load [92]. For these SMRF modules use of $\mathrm{k}_{\mathrm{t}}=0.11$ to estimate the fundamental period is most accurate for the case of rigid inter-module connection. It should be mentioned that the data presented for the MSBs considers only the main structural elements and excludes the cladding elements. Cladding incorporated into modules may have a significant effect on the fundamental period due to the additional mass.

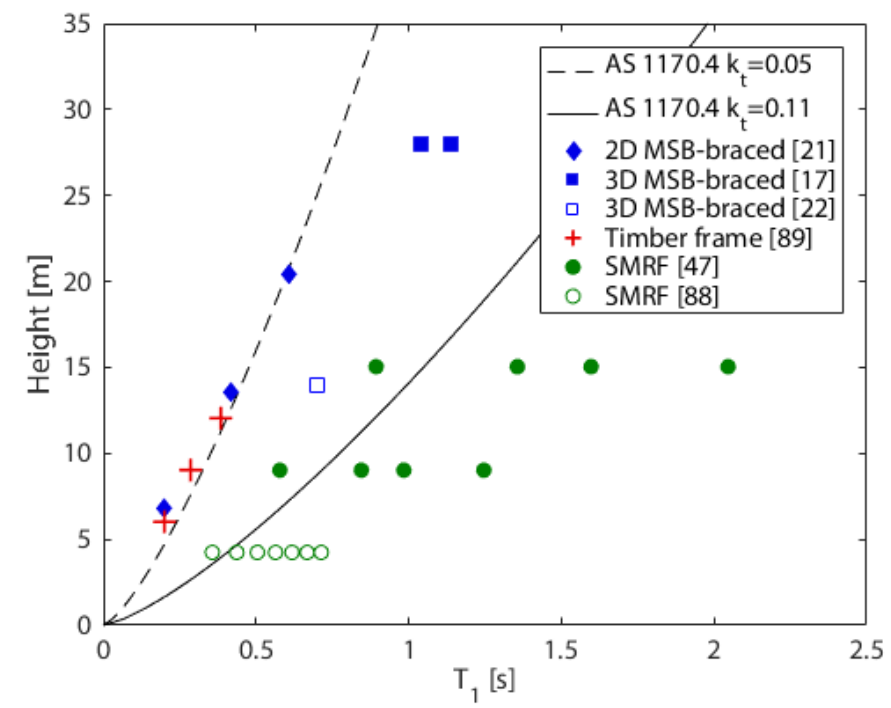

Figure 6. Variation of fundamental period with height for modular buildings

\subsection{Blast}

Blast loads can induce local and global response. Local response, typically the result of close-in 
explosion, causes localised failure which might lead to progressive collapse [94]. Global response occurs for transverse load with longer exposure time [95], such as gas explosion and far field explosion. Design is typically based on descriptive building damage level (i.e. low, medium, high) and component response. Modular buildings may be subjected to blast load from several sources including chemical / industrial / terrorist explosion. They are therefore used in industry to protect personnel [96-98] where they are referred to as blast resistant modules (BRM) or blast resistant portable buildings (BRPB) (Figure 7). Steel modules have a primary steel frame with walls formed by infill between roof and floor. For example, walls may consist of steel plate, cold-formed steel stud frame or sandwich panels. Typically, BRMs use 3.2 to $7.9 \mathrm{~mm}$ thick crimped steel plate walls fully welded to the steel frame [96]. For this type of module construction, finite element analysis is recommended to capture failure modes, although a single degree of freedom (SDOF) approach may be adopted [96]. For general design, reference is often made to the standards including UFC 3-340-02 [99] and ASCE 41088 [94]. Hao et al. [100] provide a summary of the current practice. For steel components, response limits are given based on ductility ( $\mu=1$ to 20 ), support rotation $\left(\theta=1\right.$ to $\left.12^{\circ}\right)$ and side sway (height/50 to $\mathrm{h} / 25$ ) for moment-resisting frames. Overall, published qualitative studies for blast loading are limited and further studies are needed to investigate the behaviour of mid- to highrise modular buildings.

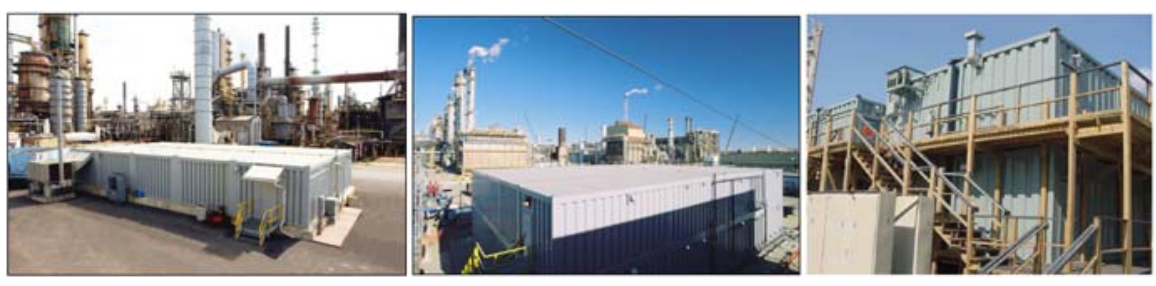

Figure 7. (L) One storey BRM building [96], (M) Two storey BRM building [96], (R) Stacked BRPB complex [97]

\subsection{Progressive collapse}

Progressive collapse occurs when local damage from an extreme event results in overload and then failure of successive alternate load paths [101, 102]. It is a relatively rare catastrophic failure which may occur due to lack of continuity, ductility and/or redundancy [101]. The methods of design are typically categorised as indirect or direct approaches. The tie force method is an indirect approach wherein robustness is enhanced by provision of specified minimum ductility, continuity and strength $[101,102]$. Direct design approaches include the alternative path method and key element design (or enhanced local resistance) [101, 102]. For modular steel buildings the tie force method may not be appropriate. This method does not consider beam rotations due to catenary action and failure may occur in low ductility 
connections such as standard fin plates [103]. Instead, the alternative load path approach is adopted [10,13]. Lawson et al. [13] completed a static analysis for the loss of one corner or internal support to a light steel module, with load being transferred by shear walls back to a tying action in inter-module connections. To demonstrate the capability of the modules, tests were completed to establish the shear wall racking capacity and deflection of the module with removed supports. The required inter-module tie forces were found to be relatively low [13]. In another study, container express (CONEX) modules used for barracks were tested in Florida [104]. The modules were stacked three levels high and connected using twist locks. The work completed included simulating column removal using SAP2000, experimental column removal tests using hydraulic jacks, and finally detonation of an artillery shell at a critical location (Figure 8). The results confirmed progressive collapse was not an issue as per the Unified Facilities Criteria [101]. Progressive collapse studies have therefore considered only light steel framed modules and container buildings stacked three storeys high. Modular steel buildings may be vulnerable due to the use of connections with limited ductility, which is worth studying. In addition, only threat-independent methods [105] have been used to assess progressive collapse and it remains to the investigate the limitations of these methods for modular building structures.

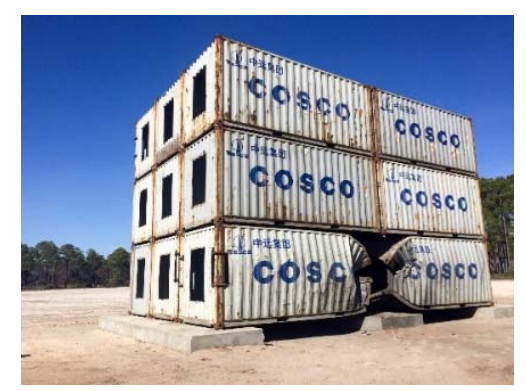

Figure 8. Expeditionary CONEX testing for progressive collapse [104]

\subsection{Fire}

Fire resistance is a major challenge for modular buildings. Concerns have been reported considering the use of flammable materials and the presence of a void between modules which may permit a fire to spread $[106,107]$. However, studies into the fire performance of modular structures are limited. One study considered fire simulation for a container building [27] and several studies investigated the performance of developing composite materials such as fibre reinforced polymer (FRP). Composite materials have advantages which make them well suited to application in modular building. They are lightweight with high strength and stiffness and offer flexibility in shape [108-111]. However, they generally have low fire resistance and their performance as a building envelope is not well known [108, 109]. Ngo et al. [108] investigated 
the performance of an office building constructed from modules with glass FRP composite components forming the façade. This study provides insight into the fire performance based on numeric analysis. Nguyen et al. [109] investigated the addition of fire retardant to improve fire performance. Models were developed to predict "fire growth index and total heat release" for "organoclay/glass fibre reinforced polymer (GFRP) laminates" [109]. The performance was then considered for an office building with façade consisting of GFRP laminate on foam core. The addition of organoclay is found to prevent flash-over and horizontal flame spread. Fire performance studies are therefore mostly related to the development of FRP materials with no studies identified for modular steel buildings. In current practice, fire resistance time requirements are satisfied by providing layers of protective cladding and fire stops to control fire spread [4].

\section{Current design practice and methodology}

\subsection{Design guidelines and theoretical analysis}

General design guidance is available for light steel framed modules in the existing literature (Table 7). In current practice, guidance is drawn from the traditional literature. A limit state approach is adopted for design criteria considering stability, strength, and serviceability. Building serviceability is satisfied by adherence to overall drift limits and acceleration limits for human comfort. For example, for wind loading, Mendis et al. [74] and Griffis [61] report on acceleration and drift limits. Modules should also satisfy serviceability criteria during transport and lifting. Limited guidance is available and current practice is based largely on practical experience. Serviceability during transport and lifting is mainly concerned with the potential for damage to finishes and equipment. Therefore, guidance can be found in existing literature such as Griffis [61]. For example, to control cracking of partition walls during transport and handling, limits of module height/500 and span/500 can be adopted for lateral acceleration and gravity loads. Design of MSB connections is similarly based on the traditional literature due to the lack of modular specific guidelines. For bolted connections, Gunawardena [17] and Styles et al. [47] showed structural behaviour can be established using finite element analysis based on comparison with laboratory testing. The resulting force-deformation or moment-rotation behaviours can then be incorporated into a simplified global model of the building structure. For example, Gunawardena [17] has demonstrated the use of link elements to model horizontal connections using ETABS and SAP2000.

As for traditional structures, simplified SDOF models are available following the standard texts such as Biggs [112], Clough and Penzien [113], and Chopra [88]. Hao et al. [100] provided a review of current practice and its limitations for blast-resistant analysis. The 
limitations of SDOF models include assumptions regarding loading conditions, response mode and deflection shape $[72,100]$. No theoretical analysis models developed specifically for modular buildings are identified in the literature. From low-rise construction, modular buildings are known to behave as rigid bodies, for example overturning and sliding due to wind loading $[114,115]$. This understanding of modular behaviour could be extended to multi-storey stacked assemblies, adopting a rigid module, flexible inter-connection approach. Extensive research has been reported on the rocking response of rigid structures. Hao and Zhou [116] provide a summary of the development up to 2011. The rocking and sliding response is known to be highly non-linear. For example, stability depends on structure slenderness, and ground motion amplitude, frequency and duration [117]. The existing knowledge of rigid bodies could be applied to modular buildings and could form the basis of theoretical analysis for multiple hazards.

Table 7. Design guidelines for modular buildings

\begin{tabular}{|l|l|}
\hline Guideline & Application scope and notes \\
\hline The Steel Construction Institute (SCI) P272 & $\begin{array}{l}\text { Architectural and general guidance on typical details for } \\
\text { light steel framed modules }\end{array}$ \\
\hline [11], SCI P302 [9], SCI P348 [14] & $\begin{array}{l}\text { General background, applications, and case studies for } \\
\text { modular buildings }\end{array}$ \\
\hline Design and Construction [3] & $\begin{array}{l}\text { General guidance on modular buildings with an } \\
\text { emphasis on light steel framed modules and case studies }\end{array}$ \\
\hline Design in Modular Construction [4] & $\begin{array}{l}\text { General guidance on transport actions for container } \\
\text { units }\end{array}$ \\
\hline $\begin{array}{l}\text { Code of Practice for Packing of Cargo } \\
\text { Transport Units [69] }\end{array}$ & $\begin{array}{l}\text { General guidance on design and construction aspects } \\
\text { with an emphasis on Australian codes and standards }\end{array}$ \\
\hline $\begin{array}{l}\text { Handbook for the Design of Modular } \\
\text { Structures [118] }\end{array}$ &
\end{tabular}

\subsection{Experimental testing}

Testing is typically conducted either to demonstrate compliance with performance requirements (i.e. proof testing) or to determine the capacity for design purposes (i.e. prototype testing). As a new developing application, structural design of modular buildings has a greater emphasis on prototype testing, rather than reliance on standardised or pre-qualified detailing. Prototype modules may be constructed to establish overall composite stiffness including cladding, test lining response to transport and lifting actions, and to test the fit and tolerance of connection systems. Table 8 gives a summary of test methods for modular buildings and prefabricated components. The documentation of test methods for modular buildings is limited and standard methods are not available in some cases. For blast loading no modular specific methods are available and a summary of current practice is provided by Hao et al. [100].

Table 8 . Test methods for modular buildings and prefabricated components

\begin{tabular}{|l|l|l|l|}
\hline Component & Test Description & Standard Method & Example \\
\hline Module & $\begin{array}{l}\text { Transport and handling - field testing, measurement } \\
\text { of wind speed/pressure, deformation \& accelerations }\end{array}$ & - & {$[70]$} \\
\hline
\end{tabular}




\begin{tabular}{|l|l|l|l|}
\hline Module & Overturning - wind tunnel, rigid body scale model & - & {$[119]$} \\
\hline Module & In-plane shear (racking test), e.g. Figure 9 & - & {$[55]$} \\
\hline Module & $\begin{array}{l}\text { Progressive collapse - general methods include } \\
\text { laboratory simulated column removal and field } \\
\text { testing }\end{array}$ & - & $\begin{array}{l}{[10,13,} \\
104]\end{array}$ \\
\hline Module & $\begin{array}{l}\text { Dynamic properties - field testing, to determine } \\
\text { fundamental frequency, damping ratio, mode shape }\end{array}$ & - & {$[93]$} \\
\hline $\begin{array}{l}\text { Module } \\
\text { frame }\end{array}$ & $\begin{array}{l}\text { Cyclic seismic test - symmetric reversed-cyclic } \\
\text { loading history }\end{array}$ & ATC-24 [120] & {$[20]$} \\
\hline $\begin{array}{l}\text { Panel - } \\
\text { wall, floor, } \\
\text { roof }\end{array}$ & $\begin{array}{l}\text { In-plane shear, compressive / tensile / concentrated } \\
\text { load, transverse flexural load (two-point or bag } \\
\text { method) }\end{array}$ & $\begin{array}{l}\text { ASTM E 564-06 } \\
{[121], \text { ASTM E }} \\
72-15[122]\end{array}$ & {$[32,123]$} \\
\hline Connections & $\begin{array}{l}\text { Evaluation of inter-module connections, e.g. Figure } \\
9\end{array}$ & - & {$[17]$} \\
\hline $\begin{array}{l}\text { Module } \\
\text { envelope }\end{array}$ & Simulated wind-borne debris impact & $\begin{array}{l}\text { ASTM E1996-14a } \\
{[124], \text { ASTM }} \\
\text { E1886-13a [125] }\end{array}$ & {$[86]$} \\
\hline
\end{tabular}
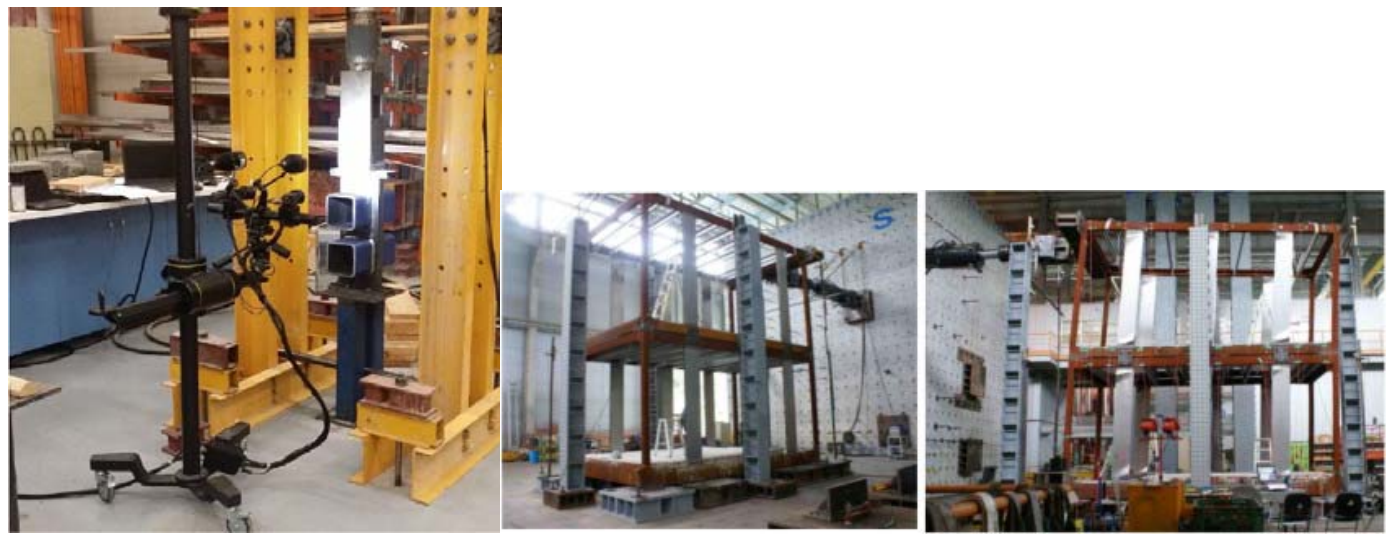

Figure 9. (L) Shear force load testing of connection with contactless strain measurement system [17], (R) Racking test of complete frame [55]

\subsection{Numerical simulation}

Structures are typically broken down into components for piecewise analysis. Connections are modelled using finite element analysis (FEA) and the resulting behaviour is incorporated in a separate model of the frame for structural analysis. MSBs often incorporate semi-rigid connections for which the behaviour and stiffness can be established for inclusion in the global analysis [126]. FEA of connections is commonly conducted using ABAQUS [127] or ANSYS $[17,47]$. For global analysis, various commercial software packages have been adopted for modular buildings, including ABAQUS [29], ANSYS [47], SAP2000 Nonlinear [19, 70], and ETABS [23]. In the specific field of earthquake engineering, RUAUMOKO 3D [24], OpenSees [22] and SeismoStruct [20] have been adopted for incremental dynamic analysis, and pushover analysis. 


\section{Conclusions}

Modular building refers to the application of a variety of structural systems and building materials. Modular buildings perform differently to similar traditional structures owing to the requirements of site interconnection for modular building. Analysis, design and construction technologies of modular building are currently under further development and several key areas are identified for further study.

(1) Overall module size is limited by transport capabilities and internal layouts are limited by the requirement for structural elements. Greater flexibility in internal layout could be provided by a reduction in structural member sizes, and reduction in the number of braces, shear walls and columns.

(2) There remains a need for efficient lightweight systems which also address issues of robustness. At the same time, there is also a need to develop new lightweight materials for specific application in prefabrication and modular building. The performance with respect to wind-borne debris impact and fire are developing areas.

(3) Accumulated damage must be considered for portable buildings subject to repeated and fatigue loading. In other cases where a module might be transported only once or twice in its life, damage during transport and in situ degradation are worth studying. This affects the performance for all hazard types, yet published quantitative studies are limited.

(4) Connections are key to the performance of modular buildings. The design and fabrication of reliable connection systems is a major challenge. Further research is required to better define the performance of existing connection systems and limit the potential for overdesign due to limited understanding.

(5) The current studies on modular building under earthquake are limited to 10 storeys. Further studies are needed to investigate the dynamic behaviour due to earthquake ground motion for mid- to high-rise modular buildings.

(6) No studies have been identified to address dynamic wind loading, or cyclonic wind loading for modular buildings. Further studies are needed to investigate the dynamic response of modular buildings under wind loading.

(7) Further studies are needed to investigate the behaviour of mid- to high-rise modular buildings subject to blast loading. In addition, progressive collapse studies considered only light steel framed modules and container buildings. Modular steel buildings may be vulnerable due to the use of connections with limited ductility, which is worth studying. 


\section{Acknowledgements}

The authors acknowledge the financial support from the Australian Government through the Australian Research Council (ARC). The first author acknowledges the support received through the Australian Government Research Training Program Scholarship.

\section{References}

[1] White RB. Prefabrication : a history of its development in Great Britain. London, England: Her Majesty's Stationery Office; 1965.

[2] Gibb AGF. Off-site Fabrication: Prefabrication, Pre-assembly and Modularisation. Scotland, UK: Whittles Publishing; 1999.

[3] Smith RE. Prefab Architecture : A guide to modular design and construction. Hoboken, NJ, USA: John Wiley \& Sons; 2010.

[4] Lawson RM, Ogden RG, Goodier C. Design in Modular Construction. Boca Raton, FL, USA: CRC Press; 2014.

[5] Lawson RM, Ogden RG, Bergin R. Application of Modular Construction in High-Rise Buildings. J Arch Eng. 2012;18:148-54. doi: 10.1061/(asce)ae.1943-5568.0000057.

[6] Kamali M, Hewage K. Life cycle performance of modular buildings: A critical review. Renewable Sustainable Energy Rev. 2016;62:1171-83. doi: 10.1016/j.rser.2016.05.031.

[7] Lopez D, Froese TM. Analysis of Costs and Benefits of Panelized and Modular Prefabricated Homes. Procedia Eng. 2016;145:1291-7. doi: 10.1016/j.proeng.2016.04.166.

[8] Annan CD. Applicability of Traditional Design Procedures to Modular Steel Buildings [PhD Thesis]. London, Ontario, Canada: The University of Western Ontario; 2008.

[9] Gorgolewski MT, Grubb PJ, Lawson RM. Modular Construction using Light Steel Framing: Design of Residential Buildings. Ascot, Berkshire, England: The Steel Construction Institute; 2001.

[10] Lawson RM, Ogden RG, Pedreschi R, Grubb PJ, Popo-Ola SO. Developments in pre-fabricated systems in light steel and modular construction. Struct Eng. 2005;83:28-35.

[11] Lawson RM, Grubb PJ, Prewer J, Trebilcock PJ. Modular Construction using Light Steel Framing: An Architect's Guide. Ascot, Berkshire, England: The Steel Construction Institute; 1999.

[12] Lawson RM, Ogden RG. 'Hybrid' light steel panel and modular systems. Thin Wall Struct. 2008;46:720-30. doi: 10.1016/j.tws.2008.01.042.

[13] Lawson RM, Byfield MP, Popo-Ola SO, Grubb PJ. Robustness of light steel frames and modular construction. Proc Inst Civ Eng Struct Build. 2008;161:3-16. doi: 10.1680/stbu.2008.161.1.3.

[14] Lawson RM. Building Design Using Modules. Ascot, Berkshire, England: The Steel Construction Institute; 2007.

[15] Lawson RM, Richards J. Modular design for high-rise buildings. Proc Inst Civ Eng Struct Build. 2010;163:151-64. doi: 10.1680/stbu.2010.163.3.151.

[16] Fathieh A. Nonlinear Dynamic Analysis of Modular Steel Buildings in Two and Three Dimensions [Master's Thesis]. Canada: University of Toronto; 2013.

[17] Gunawardena T. Behaviour of prefabricated modular buildings subjected to lateral loads [ $\mathrm{PhD}$ Thesis]. Melbourne, Australia: The University of Melbourne; 2016.

[18] Annan CD, Youssef MA, El Naggar MH. Seismic Overstrength in Braced Frames of Modular Steel Buildings. J Earthquake Eng. 2008;13:1-21. doi: 10.1080/13632460802212576.

[19] Annan CD, Youssef MA, El-Nagger MH. Effect of Directly Welded Stringer-to-Beam Connections on the Analysis and Design of Modular Steel Building Floors. Adv Struct Eng. 2009;12:373-83. doi: $10.1260 / 136943309788708400$.

[20] Annan CD, Youssef MA, El Naggar MH. Experimental evaluation of the seismic performance of modular steel-braced frames. Eng Struct. 2009;31:1435-46. doi: 10.1016/j.engstruct.2009.02.024.

[21] Annan CD, Youssef MA, El Naggar MH. Seismic Vulnerability Assessment of Modular Steel Buildings. J Earthquake Eng. 2009;13:1065-88. doi: 10.1080/13632460902933881.

[22] Fathieh A, Mercan O. Seismic evaluation of modular steel buildings. Eng Struct. 2016;122:83-92. doi: 10.1016/j.engstruct.2016.04.054.

[23] Gunawardena T, Ngo TD, Mendis P, Alfano J. Innovative Flexible Structural System Using Prefabricated Modules. J Arch Eng. 2016;22:05016003. doi: 10.1061/(asce)ae.1943-5568.0000214. [24] Gunawardena T, Ngo TD, Mendis P. Behaviour of Multi-Storey Prefabricated Modular Buildings under seismic loads. Earthquake Struct. 2016;11:1061-76. doi: 10.12989/eas.2016.11.6.1061. 
[25] Lawson RM, Ogden RG, Popo-Ola SO. Design considerations for modular open building systems. Open House Int. 2011;36:44-53.

[26] Giriunas K, Sezen H, Dupaix RB. Evaluation, modeling, and analysis of shipping container building structures. Eng Struct. 2012;43:48-57. doi: 10.1016/j.engstruct.2012.05.001.

[27] Zha X, Zuo Y. Finite Element Study of Container Structure under Normal and High Temperature. Math Probl Eng. 2016:2652149. doi: 10.1155/2016/2652149.

[28] Zha X, Zuo Y. Theoretical and experimental studies on in-plane stiffness of integrated container structure. Adv Mech Eng. 2016;8:1-20. doi: 10.1177/1687814016637522.

[29] Zuo Y, Zha X. FEM and experimental study on mechanical property of container building with holes. Int J Steel Struct. 2017;17:175-94. doi: 10.1007/s13296-015-0132-y.

[30] Boafo F, Kim J-H, Kim J-T. Performance of Modular Prefabricated Architecture: Case Study-Based Review and Future Pathways. Sustainability. 2016;8:558. doi: 10.3390/su8060558.

[31] Gunawardena T, Ngo TD, Aye L, Mendis P. Innovative Prefabricated Modular Structures - An Overview and Life Cycle Energy Analysis. International Conference on Structural Engineering Construction and Management; December; Kandy, Sri Lanka: ICSECM; 2011.

[32] Manalo A. Structural behaviour of a prefabricated composite wall system made from rigid polyurethane foam and Magnesium Oxide board. Constr Build Mater. 2013;41:642-53. doi:

10.1016/j.conbuildmat.2012.12.058.

[33] Manalo A, Aravinthan T, Fam A, Benmokrane B. State-of-the-Art Review on FRP Sandwich Systems for Lightweight Civil Infrastructure. J Compos Constr. 2017;21:04016068. doi:

10.1061/(asce)cc.1943-5614.0000729.

[34] Satasivam S, Bai Y, Zhao X-L. Adhesively bonded modular GFRP web-flange sandwich for building floor construction. Compos Struct. 2014;111:381-92. doi: 10.1016/j.compstruct.2014.01.003.

[35] Satasivam S, Bai Y. Mechanical performance of bolted modular GFRP composite sandwich structures using standard and blind bolts. Compos Struct. 2014;117:59-70. doi:

10.1016/j.compstruct.2014.06.011.

[36] Satasivam S, Bai Y. Mechanical performance of modular FRP-steel composite beams for building construction. Mater Struct. 2016;49:4113-29. doi: 10.1617/s11527-015-0776-2.

[37] Satasivam S, Feng P, Bai Y, Caprani C. Composite actions within steel-FRP composite beam systems with novel blind bolt shear connections. Eng Struct. 2017;138:63-73. doi:

10.1016/j.engstruct.2017.01.068.

[38] Abeysinghe CM, Thambiratnam DP, Perera NJ. Dynamic performance characteristics of an innovative Hybrid Composite Floor Plate System under human-induced loads. Compos Struct. 2013;96:590-600. doi: 10.1016/j.compstruct.2012.09.015.

[39] Abeysinghe CM, Thambiratnam DP, Perera NJ. Flexural performance of an innovative Hybrid Composite Floor Plate System comprising Glass-fibre Reinforced Cement, Polyurethane and steel laminate. Compos Struct. 2013;95:179-90. doi: 10.1016/j.compstruct.2012.06.019.

[40] Loss C, Davison B. Innovative composite steel-timber floors with prefabricated modular components. Eng Struct. 2017;132:695-713. doi: 10.1016/j.engstruct.2016.11.062.

[41] Loss C, Piazza M, Zandonini R. Connections for steel-timber hybrid prefabricated buildings. Part I: Experimental tests. Constr Build Mater. 2016;122:781-95. doi: 10.1016/j.conbuildmat.2015.12.002.

[42] Loss C, Piazza M, Zandonini R. Connections for steel-timber hybrid prefabricated buildings. Part II: Innovative modular structures. Constr Build Mater. 2016;122:796-808. doi:

10.1016/j.conbuildmat.2015.12.001.

[43] Pedreschi R, Brennan J, Lawson RM. Preliminary studies of steel-plywood composite structures. In: Dubina D, Ungureanu V, editors. Steel - A New and Traditional Material for Building: Proceedings of the International Conference in Metal Structures. Romania: Taylor \& Francis; 2006. p. 433-40.

[44] Lawson RM, Ogden RG, Pedreschi R, Popo-Ola SO. Developments of Cold-Formed Steel Sections in Composite Applications for Residential Buildings. Adv Struct Eng. 2008;11:651-60. doi:

10.1260/136943308787543603.

[45] Park KS, Moon J, Lee SS, Bae KW, Roeder CW. Embedded steel column-to-foundation connection for a modular structural system. Eng Struct. 2016;110:244-57. doi: 10.1016/j.engstruct.2015.11.034.

[46] Mills S, Grove D, Egan M. Breaking The Pre-fabricated Ceiling: Challenging the Limits for Modular High-Rise. In: Wood A, Malott D, editors. Proceedings of the CTBUH 2015 International Conference, New York, USA. Chicago: Council on Tall Buildings and Urban Habitat; 2015. p. 416-25.

[47] Styles AJ, Luo FJ, Bai Y, Murray-Parkes JB. Effects of joint rotational stiffness on structural responses of multi-story modular buildings. In: Mair RJ, Soga K, Jin Y, Parlikad AL, Schooling JM, editors. Proceedings of the International Conference on Smart Infrastructure and Construction. London: ICE Publishing; 2016. p. 457-62. 
[48] Chen C, Cai YQ, Chiew SP. Finite element analysis of up-down steel connectors for volumetric modular construction. In: Wald F, Chiew S-P, editors. Proceedings of the 12th International Conference on Steel, Space and Composite Structures. Prague, Czech Republic: Czech Technical University in Prague; 2014. p. 173-9.

[49] Choi K-S, Lee H-C, Kim H-J. Influence of Analytical Models on the Seismic Response of Modular Structures. J Korea Inst Struct Maint Insp. 2016;20:74-85. doi: 10.11112/jksmi.2016.20.2.074.

[50] Choi K-S, Kim H-J. An Analytical Study on Rotational Capacity of Beam-Column Joints in Unit Modular Frames International Journal of Civil, Environmental, Structural, Construction and Architectural Engineering. 2015;9:100-3.

[51] Doh J-H, Ho NM, Miller D, Peters T, Carlson D, Lai P. Steel Bracket Connection on Modular Buildings. J Steel Struct Constr. 2017;2:121. doi: 10.4172/2472-0437.1000121.

[52] Lee S, Park J, Kwak E, Shon S, Kang C, Choi H. Verification of the seismic performance of a rigidly connected modular system depending on the shape and size of the ceiling bracket. Materials.

2017;10:263. doi: 10.3390/ma10030263.

[53] Chen Z, Li H, Chen A, Yu Y, Wang H. Research on pretensioned modular frame test and simulations. Eng Struct. 2017;151:774-87. doi: 10.1016/j.engstruct.2017.08.019.

[54] Chen Z, Liu J, Yu Y. Experimental study on interior connections in modular steel buildings. Eng Struct. 2017;147:625-38. doi: 10.1016/j.engstruct.2017.06.002.

[55] Hong S-G, Cho B-H, Chung K-S, Moon J-h. Behavior of framed modular building system with double skin steel panels. J Constr Steel Res. 2011;67:936-46. doi: 10.1016/j.jcsr.2011.02.002.

[56] Ha TH, Cho BH, Kim H, Kim DJ. Development of an Efficient Steel Beam Section for Modular Construction Based on Six-Sigma. Adv Mater Sci Eng. 2016;2016:9687078. doi: 10.1155/2016/9687078. [57] Jeyarajan S, Liew JYR, Koh CG. Enhancing the Robustness of Steel-Concrete Composite Buildings under Column Loss Scenarios. Int J Protective Struct. 2015;6:529-50. doi: 10.1260/2041-4196.6.3.529. [58] Gill JC, Malamud BD. Reviewing and visualizing the interactions of natural hazards. Reviews of geophysics. 2014;52:680-722. doi: 10.1002/2013RG000445.

[59] Gill JC, Malamud BD. Hazard interactions and interaction networks (cascades) within multi-hazard methodologies. Earth Syst Dyn. 2016;7:659-79. doi: 10.5194/esd-7-659-2016.

[60] Gardoni P, LaFave JM. Chapter 1 - Multi-hazard Approaches to Civil Infrastructure Engineering: Mitigating Risks and Promoting Resilience. In: Gardoni P, LaFave JM, editors. Multi-hazard Approaches to Civil Infrastructure Engineering. Switzerland: Springer International Publishing; 2016.

[61] Griffis LG. Serviceability Limit States Under Wind Load. Eng J/AISC. 1993;30:1-16.

[62] Standards Australia. AS/NZS 1170.2:2011 Structural design actions, Part 2: Wind actions. Sydney, Australia: SAI Global Limited; 2011.

[63] CTS. Simulated Windborne Debris Impact Testing of Building Envelope Components, Version 4. Townsville, Australia: Cyclone Testing Station (CTS), James Cook University; 2017.

[64] Standards Australia. AS 1170.4-2007(+A1) Australian Standard - Structural design actions - Part 4: Earthquake actions in Australia. Sydney, Australia: SAI Global Limited; 2007.

[65] ASME. BTH-1 Design of Below-the-Hook Lifting Devices. New York, NY: The American Society of Mechanical Engineers (ASME); 2017.

[66] Duerr D. ASME BTH-1 Pinned Connection Design Provisions. Pract Period Struct Des Constr. 2008;13:53-8. doi: 10.1061/(ASCE)1084-0680(2008)13:2(53).

[67] David D. Design Factors for Fabricated Steel Below-the-Hook Lifting Devices. Pract Period Struct Des Constr. 2008;13:48-52. doi: 10.1061/(ASCE)1084-0680(2008)13:2(48).

[68] DNV GL AS. DNV-OS-H205 Lifting Operations (VMO Standard - Part 2-5). DNV GL AS; 2014. [69] IMO. Code of Practice for Packing of Cargo Transport Units (CTU Code). International Maritime Organization (IMO); 2014.

[70] Smith I, Asiz A, Gupta G. High Performance Modular Wood Construction Systems. Fredericton, Canada: Wood Science and Technology Centre; 2007.

[71] Holmes JD. Wind Loading of Structures. 3rd ed. Boca Raton, FL: CRC Press; 2015.

[72] Hao H. Predictions of Structural Response to Dynamic Loads of Different Loading Rates. Int J Protective Struct. 2015;6:585-605. doi: 10.1260/2041-4196.6.4.585.

[73] Aly MA, Abburu S. On the Design of High-Rise Buildings for Multihazard: Fundamental Differences between Wind and Earthquake Demand. Shock and Vibration. 2015:148681. doi: 10.1155/2015/148681.

[74] Mendis P, Ngo TD, Haritos N, Hira A, Samali B, Cheung J. Wind loading on tall buildings. EJSE. 2007;7:41-54.

[75] Holmes JD, Kwok KCS, Ginger JD. Wind Loading Handbook for Australia and New Zealand: Background to AS/NZS 1170.2 Wind Actions. Sydney, Australia: Australasian Wind Engineering Society (AWES); 2012. 
[76] Jeary AP, Ellis BR. On predicting the response of tall buildings to wind excitation. J Wind Eng Ind Aerodyn. 1983;13:173-82. doi: 10.1016/0167-6105(83)90139-3.

[77] Tamura Y. Chapter 13 - Damping in Buildings and Estimation Techniques. In: Tamura Y, Kareem A, editors. Advanced Structural Wind Engineering. Tokyo, Japan: Springer; 2013.

[78] Gunawardena T, Ngo TD, Mendis P, Aye L, Alfano J. Structural performance under lateral loads of innovative prefabricated modular structures. In: Samali, Attard, Song, editors. Materials to Structures:

Advancement through Innovation. London: Taylor \& Francis; 2013.

[79] Minor JE. Windborne debris and the building envelope. J Wind Eng Ind Aerodyn. 1994;53:207-27. doi: 10.1016\%2F0167-6105\%2894\%2990027-2.

[80] Wills JAB, Lee BE, Wyatt TA. A model of wind-borne debris damage. J Wind Eng Ind Aerodyn. 2002;90:555-65. doi: 10.1016/S0167-6105(01)00197-0.

[81] Minor JE. Lessons Learned from Failures of the Building Envelope in Windstorms. J Arch Eng. 2005;11:10-3. doi: 10.1061/(ASCE)1076-0431(2005)11:1(10).

[82] Chen W, Hao H. Experimental and numerical study of composite lightweight structural insulated panel with expanded polystyrene core against windborne debris impacts. Mater Design. 2014;60:409-23. doi: 10.1016/j.matdes.2014.04.038.

[83] Chen W, Hao H, Du H. Failure analysis of corrugated panel subjected to windborne debris impacts. Eng Fail Anal. 2014;44:229-49. doi: 10.1016/j.engfailanal.2014.05.017.

[84] Chen W, Hao H. Performance of structural insulated panels with rigid skins subjected to windborne debris impacts - Experimental investigations. Constr Build Mater. 2015;77:241-52. doi:

10.1016/j.conbuildmat.2014.12.112.

[85] Meng Q, Hao H, Chen W. Experimental and numerical study of basalt fibre cloth strengthened structural insulated panel under windborne debris impact. J Reinf Plast Compos. 2016;35:1302-17. doi: $10.1177 / 0731684416649787$.

[86] Meng Q, Hao H, Chen W. Laboratory test and numerical study of structural insulated panel strengthened with glass fibre laminate against windborne debris impact. Constr Build Mater.

2016;114:434-46. doi: 10.1016/j.conbuildmat.2016.03.190.

[87] NRCC. National Building Code of Canada (NBCC). Ottawa, Ontario, Canada: National Research Council of Canada (NRCC); 2005.

[88] Chopra AK. Dynamics of Structures, Theory and Applications to Earthquake Engineering. 5th ed. NJ, USA: Prentice Hall; 2016.

[89] Redwood RG, Channagiri VS. Earthquake resistant design of concentrically braced steel frames. Can J Civ Eng. 1991;18:839-50. doi: 10.1139/191-101.

[90] Khatib IF, Mahin SA, Pister KS. Seismic behavior of concentrically braced steel frames. Berkeley, CA, USA: Earthquake Engineering Research Center, University of California; 1988. p. 222 pages.

[91] Asteris PG, Repapis CC, Repapi EV, Cavaleri L. Fundamental period of infilled reinforced concrete frame structures. Struct Infrastruct Eng. 2017;13:929-41. doi: 10.1080/15732479.2016.1227341.

[92] Shirokov VS, Kholopov IS, Solovejv AV. Determination of the Frequency of Natural Vibrations of a Modular Building. Procedia Eng. 2016;153:655-61. doi: 10.1016/j.proeng.2016.08.218.

[93] Malo KA, Abrahamsen RB, Bjertnæs MA. Some structural design issues of the 14-storey timber framed building "Treet” in Norway. Eur J Wood Wood Prod. 2016;74:407-24. doi: 10.1007/s00107-0161022-5.

[94] ASCE. Design of Blast-Resistant Buildings in Petrochemical Facilities, 2nd ed. Reston, VA: American Society of Civil Engineers; 2010.

[95] Ngo TD, Mendis P, Gupta A, Ramsay J. Blast Loading and Blast Effects on Structures - An Overview. EJSE Special Issue: Loading on Structures. 2007.

[96] Summers PB. Design of Modular Blast-Resistant Steel-Framed Buildings in Petrochemical Facilities. In: Anderson DL, Bhatti MA, Foley CM, Charney FA, editors. Structures Congress 2008: Crossing Borders. Vancouver, Canada American Society of Civil Engineers; 2008. p. 1557-63.

[97] Harrison BF. Blast resistant modular buildings for the petroleum and chemical processing industries. J Hazard Mater. 2003;104:31-8. doi: 10.1016/s0304-3894(03)00232-2.

[98] Maclachlan I. Standardization of location, design and specification of temporary modular buildings on petrochemical and process sites. Loss Prevention Bulletin. 2007;196:26-30.

[99] DoD. UFC 3-340-02 : Structures to Resist the Effects of Accidental Explosions. USA: Department of Defence (DoD); 2008.

[100] Hao H, Hao Y, Li J, Chen W. Review of the current practices in blast-resistant analysis and design of concrete structures. Adv Struct Eng. 2016;19:1193-223. doi: 10.1177/1369433216656430.

[101] DoD. UFC 4-023-03 : Design of Buildings to Resist Progressive Collapse. USA: Department of Defence (DoD); 2009. 
[102] Cormie D. Whole-building response to blast damage. In: Cormie D, Mays G, Smith P, editors. Blast effects on buildings. 2nd ed. London: ICE Publishing; 2012.

[103] Byfield MP, Paramasivam S. Catenary action in steel-framed buildings. Proc Inst Civ Eng Struct Build. 2007; 160:247-57.

[104] Lawson SH. AFCEC conducts CONEX dorm field testing. 2017 [cited 2017 April 21]; Available from: http://www.afcec.af.mil/News/Article-Display/Article/1157092/afcec-conducts-conex-dorm-fieldtesting/.

[105] Sideri J, Mullen CL, Gerasimidis S, Deodatis G. Distributed Column Damage Effect on Progressive Collapse Vulnerability in Steel Buildings Exposed to an External Blast Event. J Perform Constr Facil. 2017;31:04017077. doi: 10.1061/(ASCE)CF.1943-5509.0001065.

[106] Gallagher KA. The Dangers of Modular Construction. Fire Engineering. Tulsa: PennWell Corporation; 2009. p. 95-101.

[107] Gallagher KA. Modular Construction: Hidden Hazards Within. Fire Engineering. Tulsa: PennWell Corporation; 2013. p. 73-8.

[108] Ngo TD, Nguyen QT, Tran P. Heat release and flame propagation in prefabricated modular unit with GFRP composite facades. Build Simul. 2016;9:607-16. doi: 10.1007/s12273-016-0294-3.

[109] Nguyen QT, Ngo TD, Tran P, Mendis P, Zobec M, Aye L. Fire performance of prefabricated modular units using organoclay/glass fibre reinforced polymer composite. Constr Build Mater. 2016;129:204-15. doi: 10.1016/j.conbuildmat.2016.10.100.

[110] Nguyen QT, Tran P, Ngo TD, Tran PA, Mendis P. Experimental and computational investigations on fire resistance of GFRP composite for building façade. Composites Part B. 2014;62:218-29. doi: 10.1016/j.compositesb.2014.02.010.

[111] Nguyen QT, Ngo TD, Mendis P, Tran PA. Composite materials for next generation building facade systems. Civil Eng Arch. 2013;1:88-95. doi: 10.13189/cea.2013.010305.

[112] Biggs JM. Introduction to Structural Dynamics. New York, USA: McGraw-Hill, Inc.; 1964.

[113] Clough RW, Penzien J. Dynamics Of Structures, 3rd Ed. Berkeley, CA, USA: Computers \& Structures, Inc.; 2003.

[114] Boughton GN. Tropical Cyclone Vance : damage to buildings in Exmouth. Perth, Australia: Dept. of Local Government; 1999.

[115] Boughton GN, Falck D. Tropical Cyclone George - Damage to buildings in the Port Hedland area. Queensland, Australia: Cyclone Testing Station, James Cook University; 2007.

[116] Hao H, Zhou Y. Dynamic Response of Rigid Blocks to Simultaneous Horizontal and Vertical Ground Shock. Adv Struct Eng. 2012;15:1069-82. doi: 10.1260/1369-4332.15.7.1069.

[117] Hao H, Zhou Y. Rigid Structure Response Analysis to Seismic and Blast Induced Ground Motions. Procedia Eng. 2011;14:946-55. doi: 10.1016/j.proeng.2011.07.119.

[118] Monash University. Handbook for the Design of Modular Structures. Melbourne, Australia: Monash University; 2017.

[119] Wu Z, Peng X, Zhang C. Overturning analysis of Harbor Containers based on wind tunnel test of rigid models. 2011 International Conference on Electric Technology and Civil Engineering (ICETCE). Lushan, China: IEEE; 2011. p. 544-8.

[120] ATC. ATC 24 : Guidelines for Cyclic Seismic Testing of Components of Steel Structures.

Redwood City, CA, USA: Applied Technology Council (ATC); 1992.

[121] ASTM. E564-06 : Standard Practice for Static Load Test for Shear Resistance of Framed Walls for Buildings. West Conshohocken, PA, United States: ASTM International; 2012.

[122] ASTM. E72-15 : Standard Test Methods of Conducting Strength Tests of Panels for Building Construction. West Conshohocken, PA, United States: ASTM International; 2015.

[123] Toro WM, Salenikovich A, Mohammad M, Beauregard R. Racking and Bending Tests for Prefabricated Wall Panels. MADERAS: Ciencia y technologia. 2007;9:3-14.

[124] ASTM. E1996-14a : Standard Specification for Performance of Exterior Windows, Curtain Walls, Doors, and Impact Protective Systems Impacted by Windborne Debris in Hurricanes. West

Conshohocken, PA, United States: ASTM International; 2014.

[125] ASTM. E1886-13a : Standard Test Method for Performance of Exterior Windows, Curtain Walls, Doors, and Impact Protective Systems Impacted by Missile(s) and Exposed to Cyclic Pressure Differentials. West Conshohocken, PA, United States: ASTM International; 2013.

[126] Bayo E, Cabrero JM, Gil B. An effective component-based method to model semi-rigid connections for the global analysis of steel and composite structures. Eng Struct. 2006;28:97-108. doi: 10.1016/j.engstruct.2005.08.001.

[127] Uy B, Patel V, Li D, Aslani F. Behaviour and Design of Connections for Demountable Steel and Composite Structures. Structures. 2017;9:1-12. doi: 10.1016/j.istruc.2016.06.005. 